\title{
THE KANE FRACTURE ZONE IN THE CENTRAL ATLANTIC OCEAN
}

\author{
G M PURDY \\ Department of Geology and Geophysics, Woods Hole Oceanographic Institution, Woods Hole, MA 02543 (US A) \\ PHILIP D RABINOWITZ \\ Lamont-Doherty Geological Observatory of Columbı Untversity, Palısades, NY 10964 (US A) \\ and \\ J J A VELTEROP \\ Vening Meinesz Laboratorlum, Utrecht (The Netherlands)
}

Received July 25,1978

Revised version received June 11, 1979

\begin{abstract}
The Kane fracture zone has been traced as a distinct topographic trough from the Mid-Atlantic Ridge near $24^{\circ} \mathrm{N}$ to the $80-\mathrm{m}$ y B P 1sochron (magnetic anomaly 34 ) on either side of the ridge dxis for a total of approximately $2800 \mathrm{~km}$ Major changes in trend of the fracture zone occur at approximately $72 \mathrm{~m} \mathrm{y} \mathrm{B} \mathrm{P} \mathrm{(anomaly} 31$ time) and approximately 53-63 m y B P (anomaly 21-25 time) which are the result of major reorientations in spreadıng directions in the central Atlantic Ocean
\end{abstract}

The Kane fracture zone offsets the Mid-Atlantic Ridge axis left-laterally by $160 \mathrm{~km}$ at latitude $24^{\circ} \mathrm{N}$ [1-4] and has the largest offset of all the many fracture zones in the Central Atlantic Ocean between $16^{\circ} \mathrm{N}$ and the Azores Rabınowitz and Purdy [5] have delineated a distinctive trough which is interpreted to be the fossl trace of the Kane fracture zone, from the Mid-Atlantic Ridge approximately $1700 \mathrm{~km}$ westward to about the $80-\mathrm{m}$ y $\mathrm{B} P$ isochron Major changes in the trends of the fracture zone were shown to exist near $525^{\circ} \mathrm{W}$ (magnetic anomaly $21-25$, 53-63 m y B P [6]) and $555^{\circ} \mathrm{W}$ (magnetic anomaly $31, \sim 72 \mathrm{~m}$ y B P [6]) West of these changes in trend the offsets in the magnetic lineations have been shown to be comparable to that of the active portion of the

Contribution No 4194 of the Woods Hole Oceanographic Institution Contribution No 2851 of Lamont-Doherty Geological Observatory fracture zone at the ndge crest [5] $(\sim 160 \mathrm{~km})$

If fracture zones are fossil traces of relative plate motion $[7,8]$ then one would infer that major changes in spreading direction occurred at $\sim 53-63 \mathrm{~m}$ y $\mathrm{B} P$ and $72 \mathrm{~m}$ y $B$ P However, with data only on the western limb of the fracture zone, it is equally possible that the change in direction of the trough could have been produced by an $\sim 110-\mathrm{km}$ northward migration of the fracture zone along the ridge axis and not by a change in spreading direction $\mathrm{A}$ fracture zone migration would produce a change in onientation of the trough in the same sense ( 1 e "bending" to the south) on both sides of the Mid-Atlantic Ridge A spreading direction change would result in a change of orientation in the opposite sense ( $1 \mathrm{e}$, "bending" to the north) east of the ridge In this paper we will show that the important changes in trends of the fracture that are observed west of the ridge axis are present at the conjugate location in the east and are observed in the opposite sense 
In the spring of $1976, \mathrm{R} / \mathrm{V}$ "Knorr" carried out a detalled underway geophysical survey of the Kane fracture zone east of the Mid-Atlantic Ridge The survey was directed toward complementing and extending the previous investigations of Rabinowitz and Purdy [5] The data collected on the R/V "Knorr" cruise, together with previously collected measurements in the area (over 150 crossings with an average separation of $\sim 10 \mathrm{n} \mathrm{m}$, Fig 1) now allow us to identify this deep topographic trough for $\sim 1700 \mathrm{~km}$ east of the MidAtlantic Rudge axis We show in Fig 2 line drawings of representative seismic reflection profiles at approximate conjugate locations at either side of the ridge crest No obvious patterns in variations of trough width or scarp height are observed In the region of the displaced ridge crest, the trough is continuous, narrow $(2-10 \mathrm{~km})$ and steep walled $\left(15-25^{\circ}\right)$ and about $4300 \mathrm{~m}$ in depth (e g, profiles $1 \mathrm{~A}$ and $2 \mathrm{~A}$ ) The inactive portion is characterized by precipitous escarpments and a deep trough exceeding $6000 \mathrm{~m}$ in depth nedr their eastern and western extremities (e g, Fig 2, profiles $4 \mathrm{E}-6 \mathrm{E}$ and $4 \mathrm{~W}-6 \mathrm{~W}$ ) Although the depths to seafloor are about equal in either extension of the fracture zone trough, the sedıment thicknesses are generally greater west of the ridge axis

Reliable identification of magnetic lineations near the fracture zone east of the ridge axis has proven difficult West of the Mid-Atlantıc Rudge we have been able to trace magnetic anomalies 31 to 34 immediately to the north and south of the fracture zone axis, the left-lateral offset of $160 \mathrm{~km}$ on these anomalies is sim1 lar to that observed at the ridge crest At this time only magnetic anomaly 34 has been identified south of the fracture zone trough east of the ridge crest (Fig 1)

We have plotted in Fig 3 depth to seafloor and depth to basement (from seismic reflection profiles) against the distance along the fracture zone The age scale assumes constant seafloor spreading from the present to $\sim 80 \mathrm{~m}$ y B P (anomaly 34 time) The depth-age curves are overlain, aligned with respect to the northern and southern ridge axes We observe 1-1 $5 \mathrm{~km}$ deep troughs at the ridge-fracture intersections Away from the active part of the transform on the western side we observe reasonable agreement between the observed and predicted depths between 0 and 50-60 $\mathrm{m}$ y $\mathrm{B} P$ when the depth-age curve is aligned at the northern ridge axis, reasonable agree-
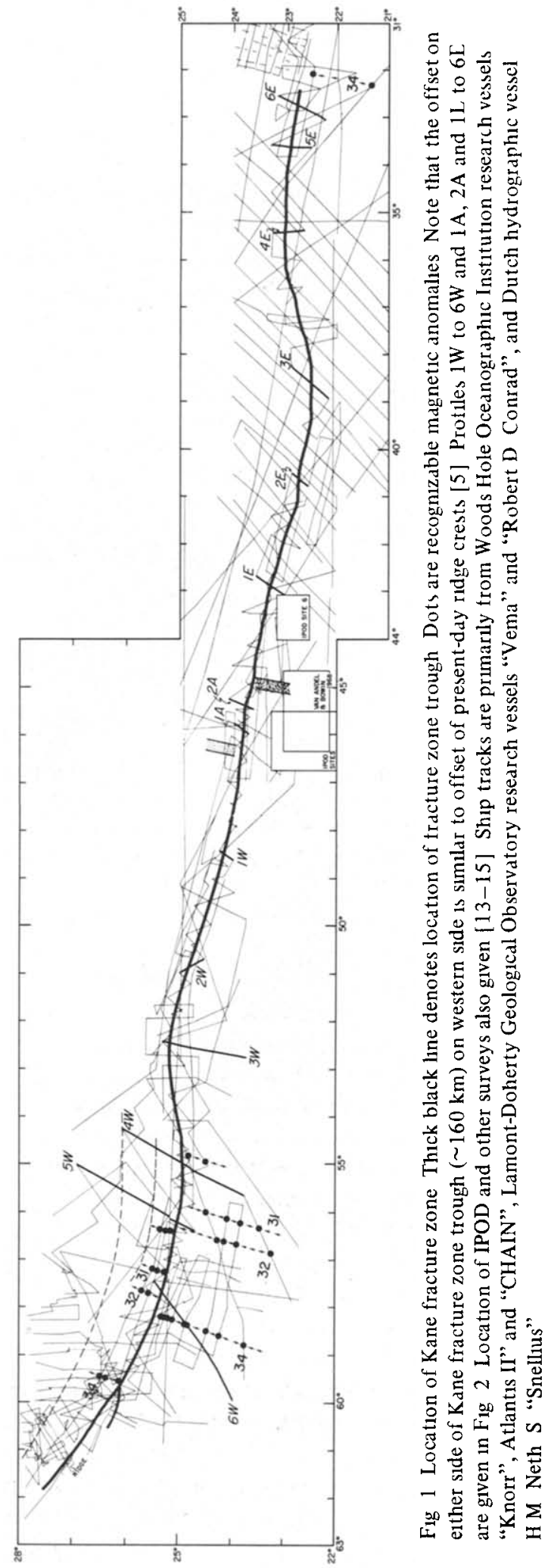
THE KANE FRACTURE ZONE

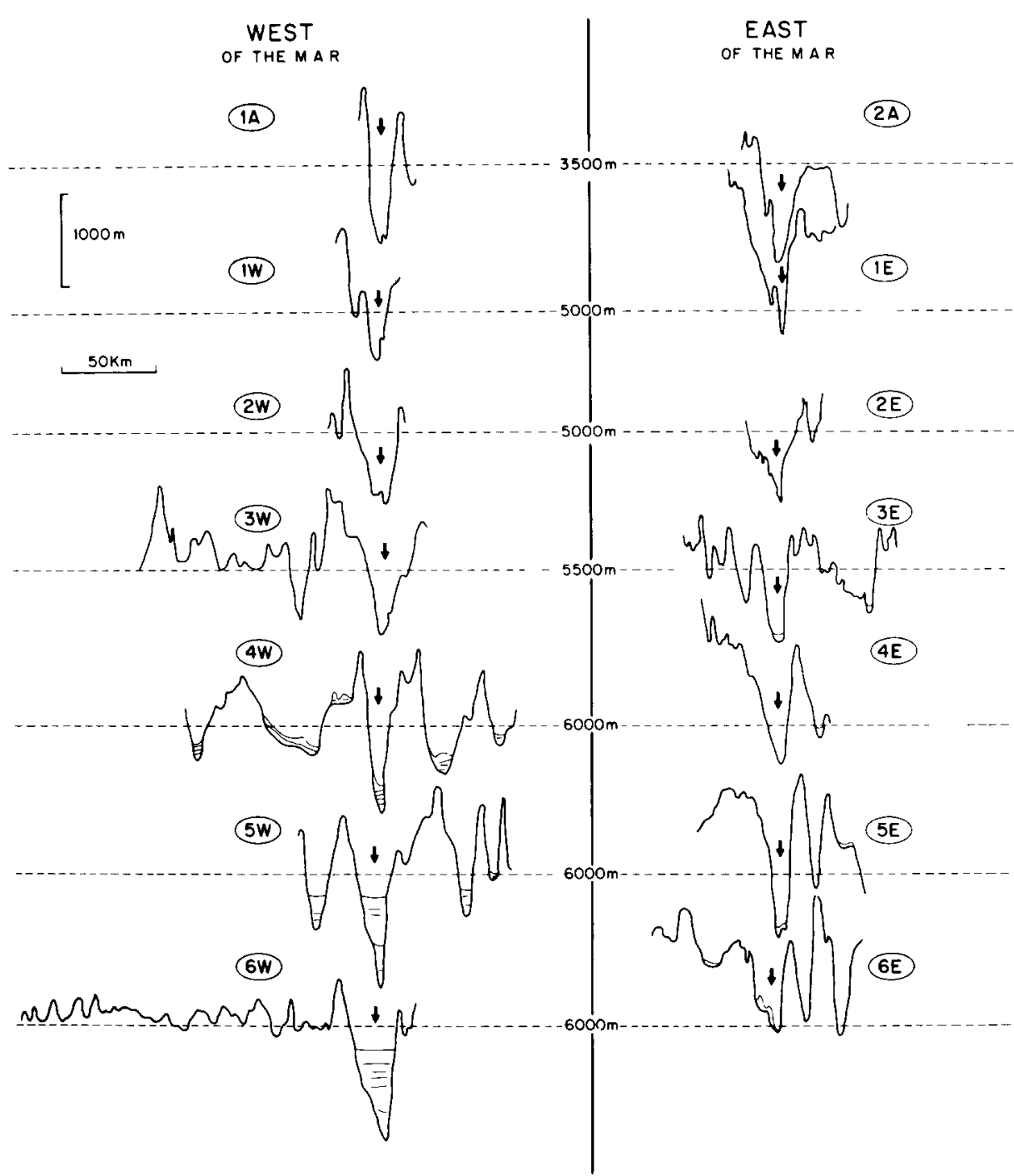

SEISMIC REFLECTION PROFILES PROJECTED PERPENDICULAR TO FRACTURE ZONE TROUGH VERTICAL

EXAGGERATION $\times 50$

Fig 2 Line drawings of representative seismic profiles across Kane fracture zone at approximate conjugate locations on either side of ridge axis ( $1 \mathrm{~W}$ to $6 \mathrm{~W}$ and $1 \mathrm{E}$ to $6 \mathrm{E}$ ) and at active transform (1A and $2 \mathrm{~A}$ ) Locations in Fig 1 Axis of fracture zone trough given by arrows

ment is also observed for this same time period on the eastern side when the depth-age curve is aligned at the southern ridge axis This suggests that no matter at which ridge crest the crust along the active transform is formed, it does not start cooling in a fashion predicted by the cooling curves until it has moved away from the thermal effects of both ndge axes, $1 \mathrm{e}$, even If material comprising the western trough was generated at the southern ridge axis, "normal" cooling would not commence until it has moved past the north. ern ridge axis The locations at which the agreement between the observed and predicted curves become 

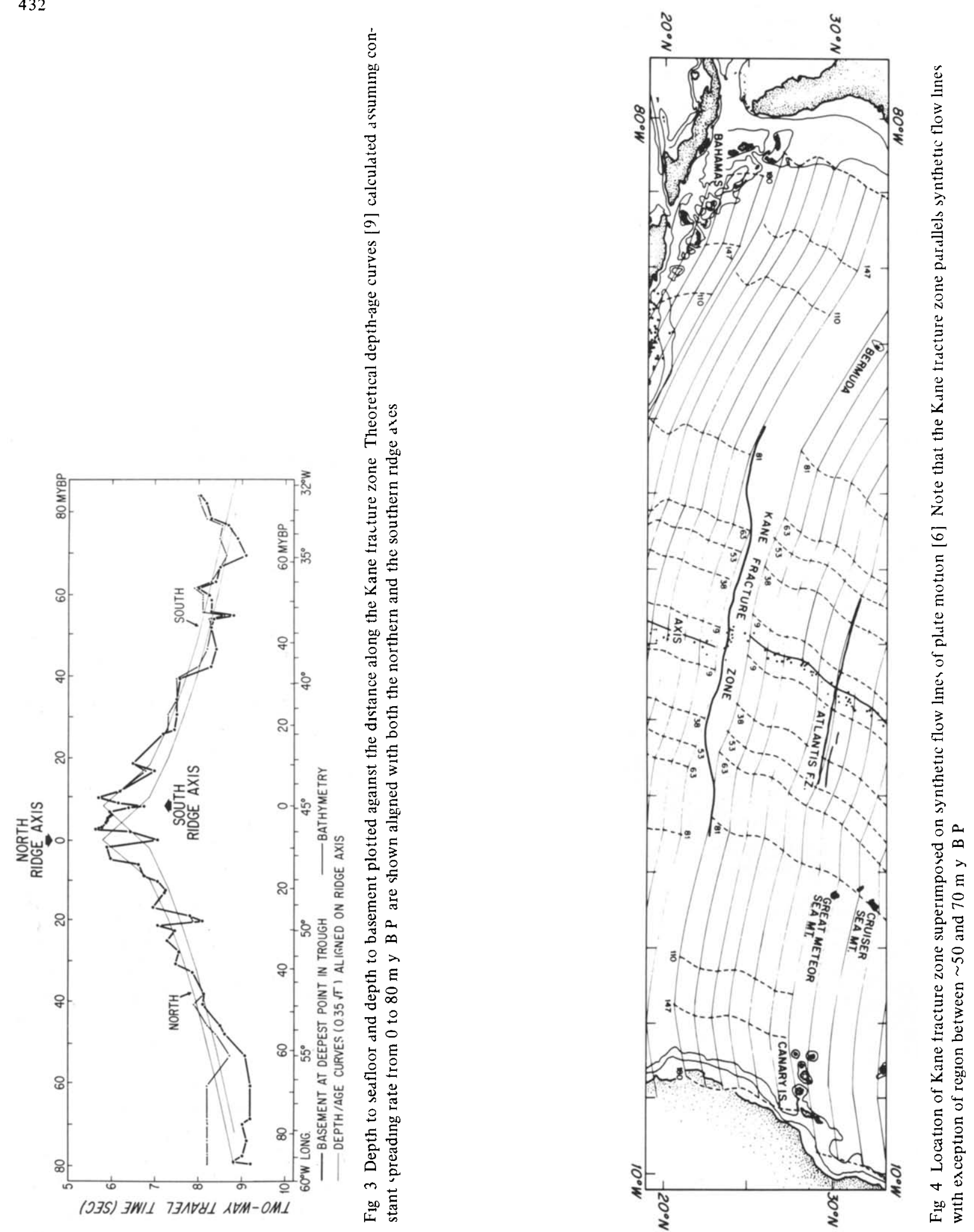
poor $\left(55\right.$ and $\left.38^{\circ} \mathrm{W}\right)$ correspond to the locations of the major changes in trend of the trough

\section{Discussion}

We suggest that these changes in trend of the fracture zone that occur dt magnetic anomaly 31 time $(\sim 72 \mathrm{~m}$ y $\mathrm{B} \mathrm{P})$ and anomaly $21-25$ time $(\sim 53-63$ $m$ y $B P$ ) result from major changes in the spreading geometry of the Central Atlantic Ocean at these times Recent investigations of the Atlantıs (J D Phillips, personal communication), Oceanographer [10] and other smaller fracture zones $[11,12]$ in the Central Atlantic Ocean, have also revealed important changes in trends and morphology along their length
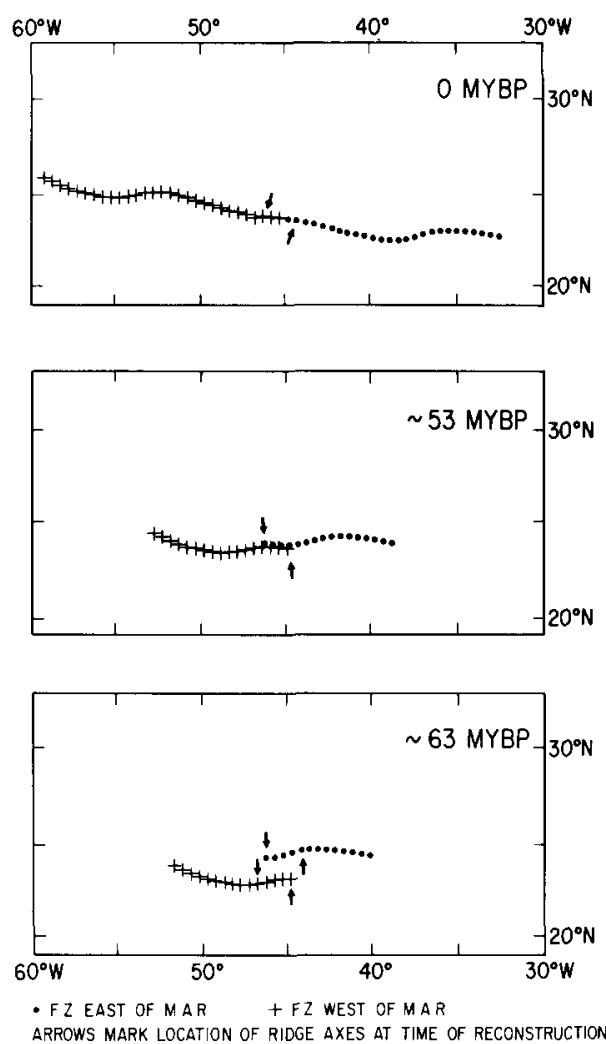

Fig 5 Reconstructions of Kane fracture zone trough to 53 and $63 \mathrm{~m} \mathrm{y} \mathrm{B} \mathrm{P} \mathrm{The} \mathrm{eastern} \mathrm{limb} \mathrm{(dots)} \mathrm{and} \mathrm{western} \mathrm{limb}$ (crosses) were rotated clockw1se and counterclockwise respectively, using the finite poles and rotations of Pitman and Talwanı [6] The rotation angle used for each limb was half the total finite rotation
We have plotted the location of the Kane fracture zone trough as described above, on the synthetic flow lines of plate motion given by Pitman and Talwani [6] (Fig 4) With the exception of the sections of the fracture zone between $\sim 525$ and $555^{\circ} \mathrm{W}$ on the western side and 36 and $39^{\circ} \mathrm{W}$ on the eastern side, the fracture zone trough closely pardllels their flow lines

In Fig 5 we show reconstructions using the finite poles and rotations given by Pitman and Talwanı [6] Their anomaly $21(\sim 53 \mathrm{~m}$ y $\mathrm{B} \mathrm{P})$ pole gives an excellent correspondence of the two fracture zone segments when they are reconstructed back to that time However, their anomaly $25(\sim 63 \mathrm{~m}$ y $\mathrm{B} \mathrm{P})$ pole gives a significant discrepancy when reconstructed

In summary, a distinct topographic trough has been traced for about $2800 \mathrm{~km}$ from $80 \mathrm{~m}$ y B P west of the ridge axis to its corresponding location east of the ridge crest Major reorientations in the trends of the trough are observed at corresponding locations east and west of the ridge crest at about $50-70 \mathrm{~m} \mathrm{y}$ B $\underline{P}$ and most probably result from major reorientations in the spreading directions in the Central Atlantic Ocean

\section{Acknowledgements}

We wish to acknowledge the officers, crew and scientists on board the R/V "Knorr" for their cooperation and assistance in gathering the data This study was supported by National Science Foundation grant OCE 76-02254 and Office of Naval Research contract N00014-75-C-022 We thank Hans Schouten and E Uchup1 for reviewing the manuscript and making helpful suggestions for improvement

\section{References}

1 G M Purdy, P D Rabinowitz and H Schouten The MidAtlantic Ridge at $23^{\circ} \mathrm{N}$ bathymetry and magnetics, in W G Melson, P D Rabinowitz et al Initial Reports of the Deep Sea Drilling Project, 45 (U S Government Printıng Office, Washıngton, D C , 1978) 119

2 G M Purdy and P D Rabinowitz The Kane fracture zone at the Mid-Atlantic Ridge IPOD sites 395 and 396, in W G Melson, P D Rabınowitz et al Initial Reports of the Deep Sea Drllling Project, 45 (U S Government Prıntıng Office, Washington, D C , 1978) color map supplement

3 L R Sykes Mechanısm of earthquakes and nature of 
faulting on the mid-ocean ridge, I Geophys Res 72 (1967) 2131

4 P J Fox, W C Pitman III and F Shepdrd Crustal plates in the central Atlantic evidence for at least two poles of rotdtion, Science, 165 (1969) 487

5 P D Rabinowitz and G M Purdy The Kane fracture zone in the western Central Atlantıc Ocean, Earth Planet Sc1 Lett 33 (1976) 21

6 W C Pitman and M Talwanı Sed-floor spreadıng in the North Atlantk Geol Soc Am Bull v 83 (1972) 619

7 W J Morgan Rises, trenches, great faults and crustal blocks, J Geophys Res 73 (1968) 1959

$8 \mathrm{X}$ Le Pichon Sea-floor spreading and continental drift, J Geophys Res 73 (1968) 3661

9 B Parsons and $\mathbf{J}$ Sclater An analysis of the variation of ocean floor bathymetry and heat flow with age, J Geophys Res 82 (1977) 803

10 P J Fox, S W Schroeder, R H Moody W C Pitman III and $\mathrm{P} J$ Hoose, The bathymetry of the Oceanographer tracture zone and Mid-Atlantic Ridge at $35^{\circ} \mathrm{N}$ with implications for Central North Atlantic plate motions, J Geol Soc, London (in press)
11 B J Collette, H Schouten $\mathbf{h}$ Rutten and A P Slootweg, Structure of the Mid-Atlantic Ridge province between $12^{\circ}$ and $18^{\circ}$, Mar Geophys Res 2 (1974) 143

12 P R Vogt, G L Johnson, T L Holcombe J G Gilg and A E Avery Episodes of sed-floor spreading recorded by the North Atlantic basement Tectonophy sics, 12 (1971) 211

13 P D Rabinowitz, G Melson, H Bougault, T Гujı, A L Graham, H P Johnson J Lawrence, J Natland E Prosser, M Rhodes and B P Zolotarev Challenger Drills on Leg 45, Geotımes 21/4 (1976) 20

14 L V Dintriev, J R Heirtzler, H Dick, M Dungan, A Enckson, $\mathrm{F} N$ Hodges, J Honnorez, J Kirkpdtrkk, D Matthews, D Ohnenstetter, N Peterson $H$ Sato and H Schmincke Drilling into ocean crust Leg 46 Geotımes, Sept (1976) 21

$15 \mathrm{~T} \mathbf{H}$ Van Andel and C O Bown Mid-Atlantic Ridge between $22^{\circ}$ and $23^{\circ}$ north latitude and the tectonics of midocean rises, J Geophys Res, 73 (1968) 1279 